\title{
Science and rock
}

\author{
How music festivals can boost the progress of science
}

\author{
Maria João Leão \& Sílvia Castro
}

S cience, more than ever, ought to be seen as a socio-cultural activity. It is a collective enterprise involving scientists and the public, aimed at understanding the world and contributing to a better standard of living, either by having an impact on technological developments or healthrelated issues. Yet, the perception of science and scientists among the public is not always positive. New scientific and technological developments can sometimes be greeted with disinterest, scepticism or even fear, due largely to misinformation, political agendas and a lack of understanding of science in the public sphere. As such, there is a clear need to improve scientific education at all levels, both in schools and universities, as well as among the general public.

Informal environments can be important in promoting public engagement with science-related issues. Schools cannot act alone, and evidence shows that non-school settings, which are often overlooked, can strongly stimulate and contribute to science learning [1,2]. Informal environments have two main benefits: the first is the awareness, motivation and excitement that learners experience when discovering science in an informal setting; the second is that people are more comfortable and able to interact more easily with science without feeling overwhelmed.

Although tacit and not always as scientifically accurate as more formal education, science learning within informal environments can still have a positive influence on the academic success of students, as well as on the likelihood that they will ultimately consider a science-related career. Such experiences can also promote informed engagement in civic science-related issues such us environmental concerns, policies and fundraising.
Importantly, learning science within these environments should be developed through partnerships between scientific institutions, local communities, funding bodies, government agencies and volunteers, all of which need to understand the overall value of science to society to engage with the project [3].

M usic festivals offer important advantages as informal venues for learning about science because they are interactive. This makes it possible for participants to engage emotionally and cognitively, and encourages them to extend their science learning over time. Importantly, festivals offer access to members of the public who would be unlikely to attend events such as science fairs or science cafés. The UK group Guerilla Science (http://guerillascience.co.uk), for example, has demonstrated the positive impact that these kinds of unexpected encounter with science and art can have on the public perception of science.

\section{...non-school settings, which are often overlooked, can strongly stimulate and contribute to science learning}

In recent years, commercial brands have begun to see the potential of music festivals as a valuable channel to reach young people. However, rather than using traditional advertising, brands allow consumers to engage with them through different experiences in what is called 'experimental marketing' $[4,5]$. What is not so common, however, is that event organizers give scientists the opportunity to engage young people in the same way.
To address this deficit and raise the profile of science at music festivals, António Coutinho, the Director of the Instituto Gulbenkian de Ciência (IGC), and Álvaro Covões, the Director of Everything is New, which organizes the popular Optimus Alive Oeiras music and art festival in Portugal, announced a new partnership between the two organizations in May 2008. In a press conference, the Directors explained the impact that they hoped bringing science to music festivals might have on the public understanding of science, while music journalists were surprised to find themselves interviewing scientists about their daily lives and research. Importantly, the Directors announced that the partnership would include a financial component, such that revenue from the festival would be used to fund fellowships at the IGC.

E our years later and the partnership is still going strong. In 2011, the Coldplay concert at Optimus Alive Oeiras was sold out and fans were treated to all their favourite songs. What they were not expecting was that they would also interact with scientists from the IGC. Despite the proximity of the IGC to the festival venue, this was probably the first time that many of them had even thought about the institute, what it does and who works there.

At the IGC stand, close to the main stage, science and music mix in unexpected ways. Different science-related activities are used to engage visitors. Revellers queue to speak with scientists (Fig 1), extract DNA from strawberries by using everyday reagents, make flavoured icecream frozen in liquid nitrogen and find out how our genes determine eye colour, the alignment of little fingers, ear shape and the ability to roll your tongue. Visitors 
can take home a microcentrifuge tube containing strawberry DNA and, hopefully, a desire to know more about science and scientists. There are also 'sci-arts' installations and photo exhibitions about the research projects and young scientists sponsored through the partnership.

The highlight of the activities at the festival, however, is probably the 'speeddating' with scientists (Fig 2). This event takes the form of a five-minute conversation between a festival-goer and a scientist in a relaxed and entertaining space. The conversations serve to break down stereotypes of scientists, encourage interest in careers in science and involve the public in scientific research. The questions asked are often insightful, surprising and thoughtful: "will we have a vaccine against cancer?"; "what degree should I take to be a scientist?"; "does a scientist also listen to music?" or even "is it safe to eat genetically modified food?" The IGC researchers who take part range from PhD students and postdocs to group leaders. They all have different backgrounds including biology, physics, bioinformatics, medicine and chemistry. The topics of conversation range from the latest work on genetics or cancer to more general questions about what motivates scientists, the day-to-day life of researchers and how research fits in with a private life. Conversations frequently last more than the allotted five minutes and the visitors have the opportunity to speak with at least three scientists from the IGC.

$\mathrm{T}$ he feedback from festival-goers is excellent. The opinions offered in the surveys of visitors are overwhelmingly positive: "I loved the enthusiasm of the scientists. Keep going like that. I also want to be a scientist," wrote one respondent. "Very interesting initiative. I'm not from the natural sciences area but it was great to meet with scientists that open the doors of their research to us. Knowledge is never too much," commented another. "This initiative was a success and we hope it happens again." The surveys also reveal that visitors to the IGC space in the last four years-around 600 people each year-are mostly teenagers and young adults: 29\% are between 13 and 19 years old, and 51\% are between 20 and 29 years old. Only $15 \%$ of the visitors are between 30 and 39 years old, $4.5 \%$ are over 40 years old, and only $0.5 \%$ are under 13 years old.

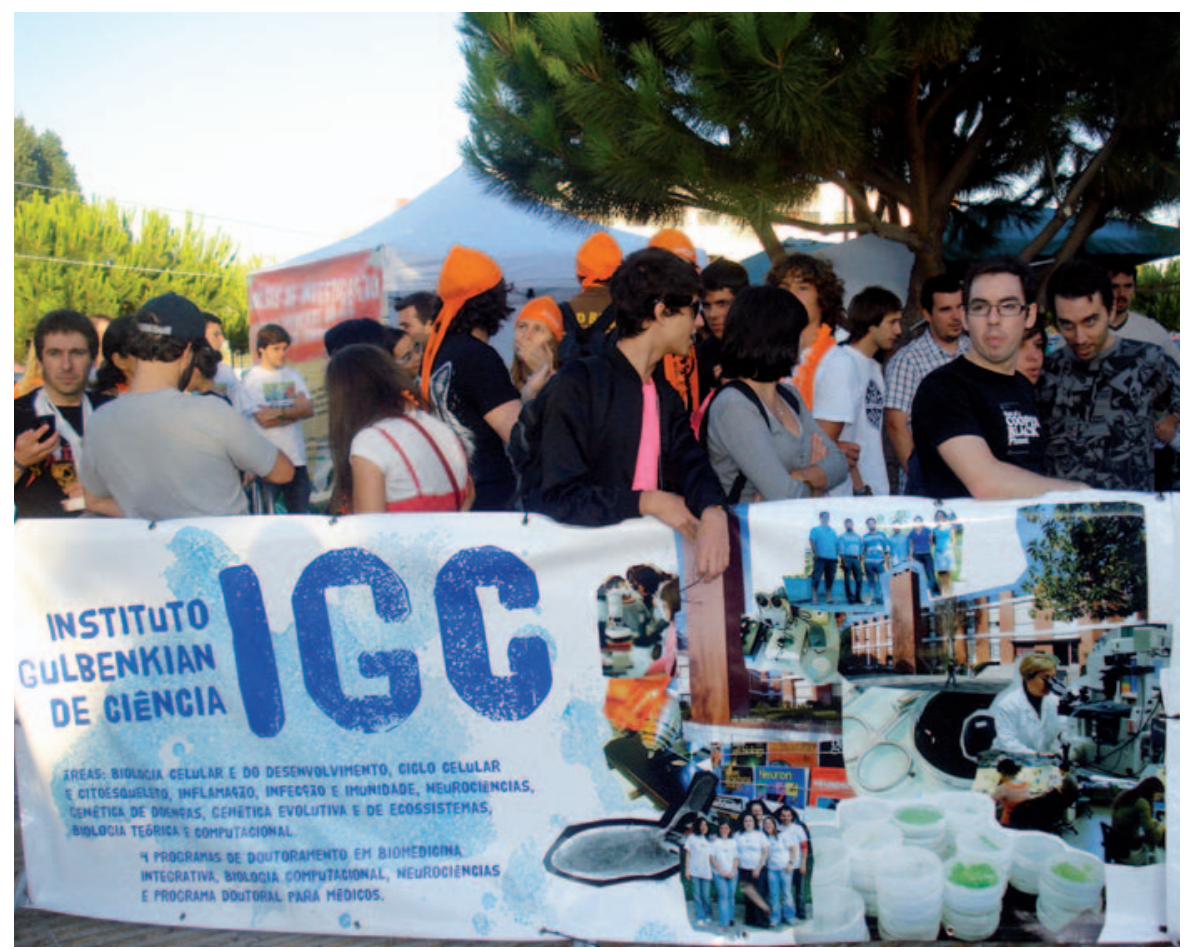

Fig 1 | The Instituto Gulbenkian de Ciência booth at Optimus Alive Oieras in 2009. Festival-goers queue to meet scientists and conduct miniature science experiments, introducing them to science in an informal and enjoyable learning environment. Photo courtesy of Instituto Gulbenkian de Ciência.

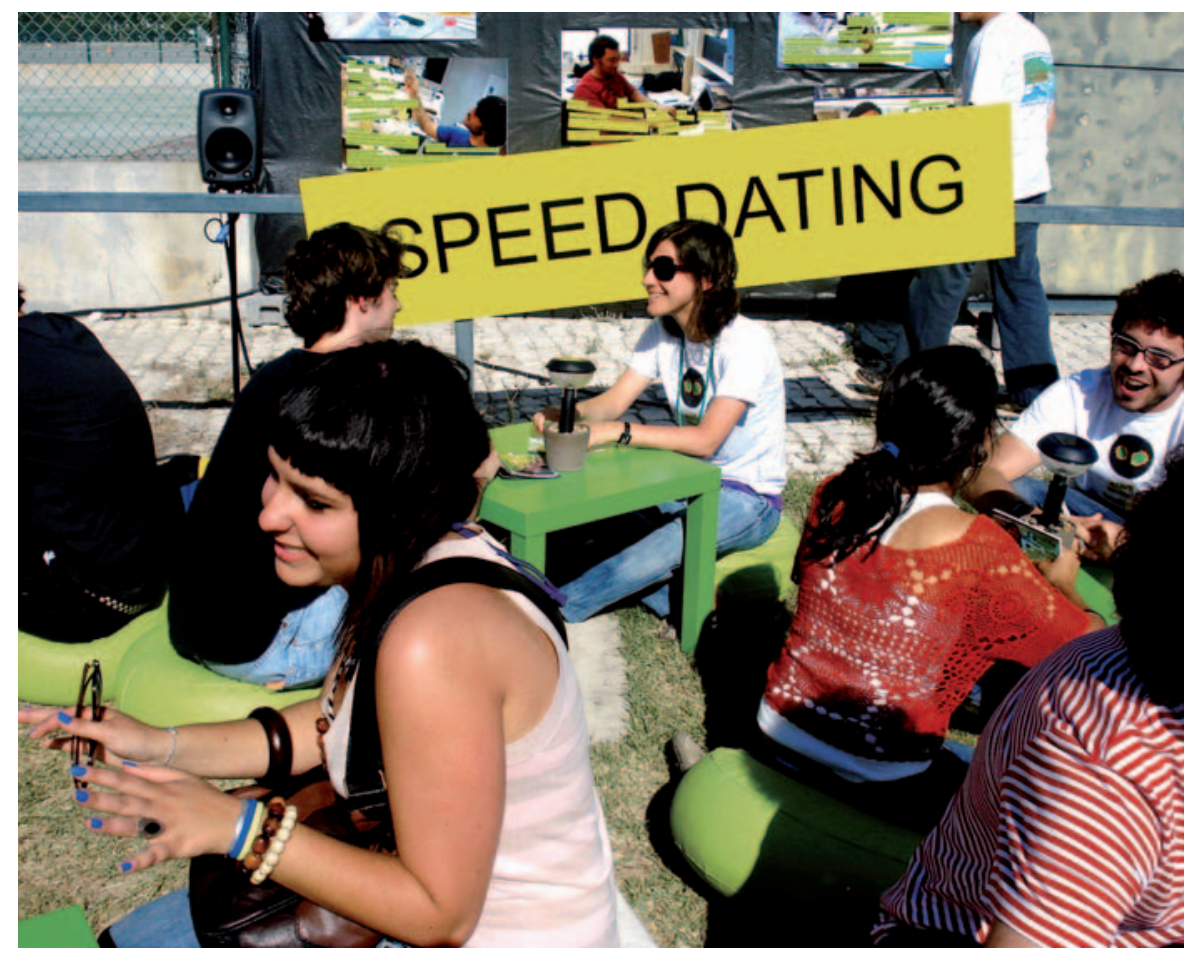

Fig 2 | Speed-dating with scientists. Members of the public get five minutes to sit and talk with an Instituto Gulbenkian de Ciência scientist about life as a researcher, science and the latest research. Conversations often go on for more than five minutes and the interactions are rewarding for all participants. Photo courtesy of Instituto Gulbenkian de Ciência. 


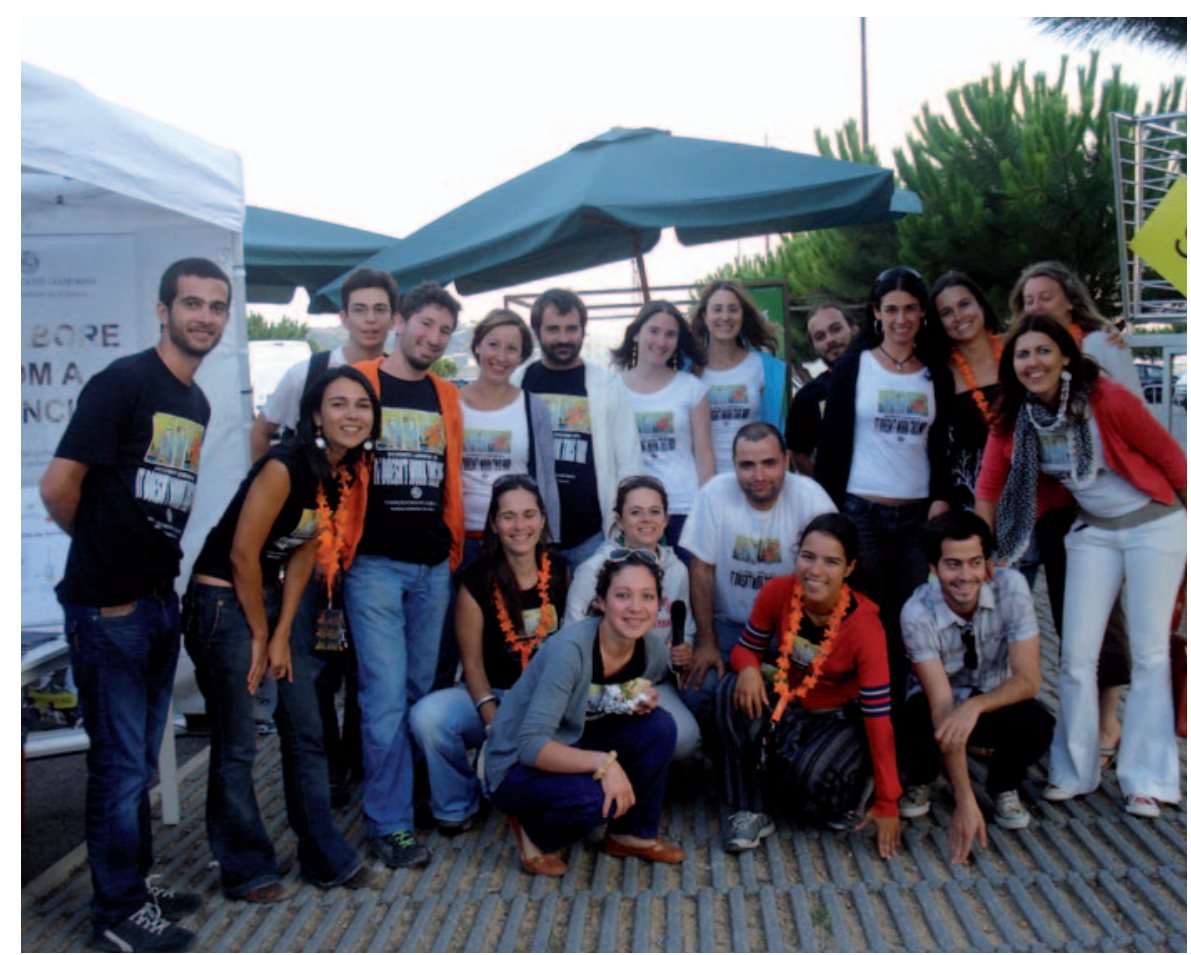

Fig 3 | The Instituto Gulbenkian de Ciência volunteers at Optimus Alive Oieras in 2009. Photo courtesy of Instituto Gulbenkian de Ciência.

Sidebar A | João Alves: 2009 Optimus Alive Oeiras-Instituto Gulbenkian de Ciência (IGC) fellow

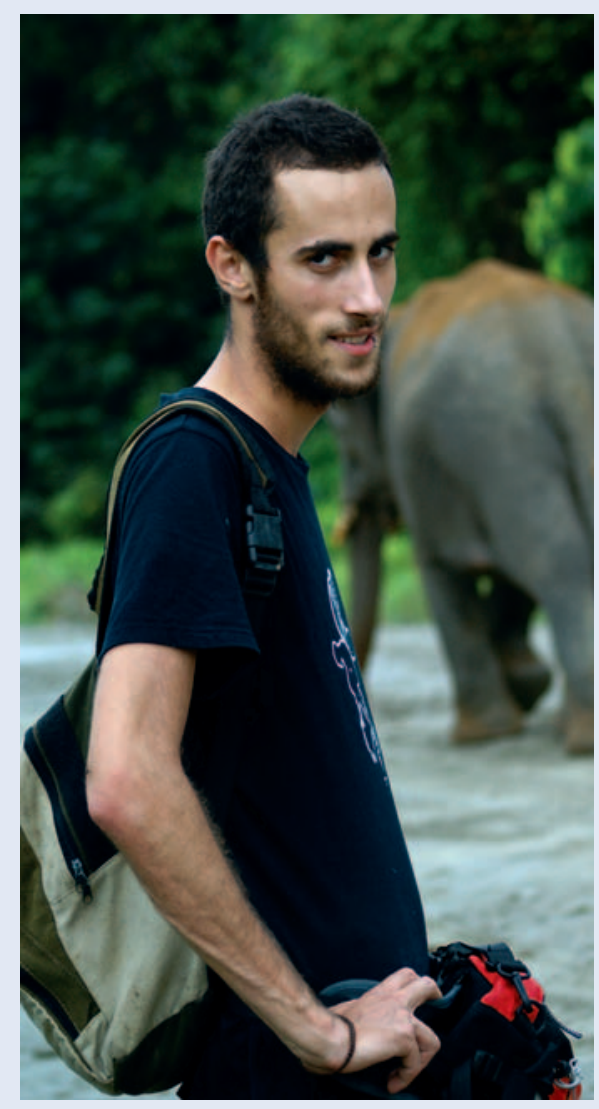

João Alves was the recipient of one of the first Optimus Alive Oeiras-IGC Fellowships. He applied when he was 24 years old, having graduated in Biology at Minho University, in Braga, in the north of Portugal. During the fellowship, he worked with the Population and Conservation Genetics team at the IGC, studying the effects of habitat loss on the fragmentation of threatened species, such as the Bornean asian forest elephant (Elephas maximus borneensis) and the Bornean orangutan (Pongo pygmaeus). He spent four months in Malasia on Borneo Island where he conducted research for the project. After finishing his fellowship, Alves was accepted for the Graduate Programme in Areas of Basic and Applied Biology (GABBA) in Portugal where he is developing his $\mathrm{PhD}$ research project on the impact of chromosomal inversions on the evolution of the human genome. "I found out about this fellowship from a leaflet I received at the entrance of the music festival Optimus Alive Oeiras 2008 on my way to the Rage Against the Machine concert. This fellowship allowed me to experience my first contact with an endangered species, the most amazing expedition to Borneo Island and participation in different research projects in biodiversity," Alves said.

Image: João Alves. Photo courtesy of Nurzhafarina Othman.
Web-based platforms have also been used successfully to disseminate the activities and results of the initiative. On the music festival website and its Facebook page, which are visited by thousands of people each day, a section on science is highlighted describing the partnership and the activities at the IGC space. Additionally, a Facebook page was created by the IGC, which allows the winners of the fellowships to interact with the general public (www.facebook.com/BolsasOptimus AliveOeirasIGC). On YouTube, three videos of the IGC presence at the festival, prepared by the IGC, are also available (http://www. youtube.com/user/lGCiencia).

This feedback and interaction is particularly pleasing, as teenagers are a notoriously difficult audience for science engagement. If we aim to increase the number of people pursuing scientific careers, we must find new ways to attract this age group to sciencerelated issues. According to the European Commission, Europe will need one million more researchers by 2020 than it has at present, and it is urgent that we find new ways to attract young people to careers in science [6]. A study of American teenagers shows that a lack of contact with scientists in their daily lives, and a lack of understanding of what scientists do, discourages young people from pursuing careers in scientific areas. As such, contact with motivated scientists could change these attitudes toward science and scientific careers [7].

Having scientists present alongside pop stars is also a good way of showing that scientists spend their free time similarly to other people, by attending social and entertaining activities. Hopefully, this juxtaposition breaks down barriers and engages teenagers from multiple backgrounds with a broad range of interests and musical tastes. Young adults, another age group present at music festivals, are also an extremely important audience for science communication. Although they might have finished their formal education, their interest and engagement in scientific issues is still extremely important to society.

0 cientists gain important experiences and skills from working at the festival. For the last four years, around 70 scientists per year, mainly from the IGC, have volunteered for the IGC space at the festival (Fig 3). Science communication skills are fundamental to scientific career progress and personal fulfilment. A survey carried out by the European Molecular Biology 
Table 1 | Projects funded by Optimus Alive Oeiras-IGC Fellowships

\begin{tabular}{lllll}
\hline Year & Fellow & Project title & Research team at IGC & International collaborative work \\
\hline 2011 & Célia Rodrigues & $\begin{array}{l}\text { Habitat loss and fragmentation in } \\
\text { Madagascar, a biodiversity hotspot }\end{array}$ & $\begin{array}{l}\text { Population \& Conservation } \\
\text { Genetics }\end{array}$ & $\begin{array}{l}\text { University of Mahajanga, Madagascar; } \\
\text { University of Antsiranana, Madagascar }\end{array}$ \\
\cline { 2 - 5 } & Diogo Santos & $\begin{array}{l}\text { How can an ancient genomic infection still } \\
\text { cause diseases after millions of years? }\end{array}$ & $\begin{array}{l}\text { Computational Genomics } \\
\text { \& Lymphocyte Physiology }\end{array}$ & $\begin{array}{l}\text { Technological Advances for Genomics } \\
\text { and Clinics (TAGC), France }\end{array}$ \\
\hline \multirow{2010}{*}{ Francisco Freixo } & $\begin{array}{l}\text { Population-based study in the São Tomé } \\
\text { and Principe Islands to understand the } \\
\text { genetic basis of resistance and susceptibility } \\
\text { to disease }\end{array}$ & Disease Genetics & $\begin{array}{l}\text { Dr Dias da Graça Hospital, } \\
\text { Principe }\end{array}$ \\
\cline { 2 - 5 } & Sam Viana & $\begin{array}{l}\text { Impact of habitat fragmentation on the } \\
\text { genetic diversity of lemur species }\end{array}$ & $\begin{array}{l}\text { Population \& Conservation } \\
\text { Genetics }\end{array}$ & University of Mahajanga, Madagascar \\
\hline 2009 & Alexandre Leitão & $\begin{array}{l}\text { Towards the evolutionary origin of immune } \\
\text { regulation: characterizing haemocyte } \\
\text { sub-populations in Drosophila }\end{array}$ & $\begin{array}{l}\text { Evolution, Development } \\
\text { \& Lymphocyte Physiology }\end{array}$ & King's College, UK \\
\cline { 2 - 6 } & João Alves & $\begin{array}{l}\text { Habitat fragmentation and conservation } \\
\text { genetics in large mammals }\end{array}$ & $\begin{array}{l}\text { Population \& Conservation } \\
\text { Genetics }\end{array}$ & Danau Girang Field Centre, Malaysia \\
\hline
\end{tabular}

IGC, Instituto Gulbenkian de Ciência.

Organization (EMBO; Heidelberg, Germany) found that senior life scientists believe that $\mathrm{PhD}$ and other postgraduate training programmes should give more attention to scientific communication, both public and peer-to-peer, and that these transferrable skills should be developed early and regularly updated $[8,9]$. Another survey by People Science \& Policy (PSP), commissioned by the Royal Society, Research Councils UK and the Wellcome Trust, showed that although lack of time is a constraint, scientists want to engage more with the public, especially with policy-makers, students and industry, and that it is important that scientific institutions and other organizations find ways to facilitate public engagement by scientists [10]. As one volunteer expressed: "I have to acknowledge Everything is New and the IGC for this prestigious opportunity, as this is a new challenge for me and is a way of bringing science closer to the general public."

l $\mathrm{n}$ addition to the value of engaging the public with science, the partnership has important financial benefits for the IGC. Fundraising is a key aspect of the partnership, which highlights the importance of private funding for biomedical research in Portugal. Everything is New, the festival promoter, supports two research fellowships per year for graduates in areas such as biodiversity, genetics and evolution. Since 2009, Optimus Alive Oeiras-IGC Research Fellowships have given young science graduates the opportunity to pursue research in areas that interest them (Sidebar A). Each fellowship is for a 12-month period and is carried out partly at the IGC and partly at a foreign institute (Table 1). Strategically, this partnership aims to secure private funding to encourage graduates to take up careers in research. Over the past three years, more than 300 graduates have applied for Optimus Alive Oeiras-IGC Fellowships and most applicants were, at the time of their application, unemployed or employed in non-science-related jobs that did not motivate them.

\section{Music festivals offer important advantages as informal venues for science learning because they are interactive}

The fellowships are also important for research groups at the IGC, as it provides the opportunity for them to have new members join their research teams. Sam Viana, one of the Fellowship recipients in 2010, has already published work developed during his fellowship, as a member of the Population and Conservation Genetics team at the IGC [11].

The private funding of science is not new. In the USA and the UK in particular, the private sector is a major source of funding for scientific institutions. In the UK, for example, medical research charities spend more than $£ 500$ million ( $€ 800$ million) each year on biomedical research [12]. In Portugal, science is still highly dependent on government funding, and the private funding of scientific research is still immature when compared with other countries [13]. One of the main reasons is the low number of research organizations that have developed communication and fundraising strategies at a professional level. Nevertheless, in the past few years, science communication and the private funding of science have substantially improved in Portugal. Additionally, Portuguese businesses are starting to take seriously so-called 'corporate social responsibility' (CSR), which makes biomedical research and science in general a potentially interesting sector for companies to invest in at the level of their CSR strategies. Another contribution has been the implementation of the Law of Scientific Sponsorship (Lei do Mecenato Científico), which provides tax relief for sciencerelated donations for both companies and individuals. Fundraising initiatives such as the IGC partnership with Optimus Alive Oeiras festival are excellent opportunities to raise funds and increase the visibility of a specific cause or of science in general.

In a period of serious economic crisis in Portugal, both European and national guidelines emphasize the need for science and technology to drive the recovery of the country. Engaging society in sciencerelated issues and finding alternative ways to fund research are crucial for scientific progress in Portugal. We hope the partnership between the Instituto Gulbenkian de Ciência and Everything is New, in addition to all the outcomes described, can be seen as a successful example in a small country for other research organizations and private companies to follow. 
I n July 2011, a second press conference was held about this long-term partnership. The Directors of the two organizations awarded prizes to the four winners of the Optimus Alive Oeiras-IGC Fellowships completed so far, and announced the new fellowships for 2011. Each student presented their results and spoke about their experience of being part of the partnership and how the fellowship had contributed to their career.

This year's festival took place between 13 and 15 July, and The Cure and Radiohead were in the line-up. Scientists were once again mixed up in the festival crowd, some anonymously, as if they were any other music fan, others were identified, doing speed-dating with festival visitors and discussing their lives as scientists. Meanwhile, the two students awarded with Optimus Alive Oeiras-IGC Fellowships in 2011 are finishing their work at the IGC, thinking about their new projects, discovering that much like the music of the festival, science also rocks.

\section{ACKNOWLEDGEMENTS}

We acknowledge everyone who helped to make this project possible over the past five years. Everything is New: Á. Covões, C. Gonçalves, N. Vieira and I. Van Krieken. Instituto Gulbenkian de Ciência: A. Coutinho, J. Demengeot, L. Chikhi, A. Godinho, C. Penha-Gonçalves, É. Sucena, J. Leal, T. Carvalho, T. Carneiro, M. Dias, M. Rebelo, S. Lima, S. Moreira, V. Faustino, C. Júlio, F. Barbosa, I. Crisóstomo, A. Mena, G. Martins, S. Dias, H. Almeida, P. Miranda, I. Pais, S. Catita, M. Teixeira, I. Bento, F. Marta and all IGC volunteers. Optimus Alive Oeiras-IGC fellows: J. Alves, A. Leitão, F. Freixo, S. Viana, D. Santos and C. Rodrigues. Fundação Calouste Gulbenkian: D. Lucena and E. Caramelo. High-school collaborations: C. Marinho (teacher) and T. Fonseca (student). Sci-art, movies and music at the IGC stand: M. Menezes, P. Almeida, R. Montalvor, C. Archer, The Brunch, S. Pais and M. Lessa. Proof-reading: J. Regan. Institutional collaborations: Design, Designways; Champimóvel, Fundação Champalimaud; Molecular cooking, Cooking Lab; and Hip-hop, Diálogo em Acção.

\section{CONFLICT OF INTEREST}

The authors declare they have no conflict of interest.

\section{REFERENCES}

1. Griffin JM (1998) School-Museum Integrated Learning Experiences in Science: A Learning Journey. Dissertation, Univ Technology, Sydney

2. Falk JH, Dierking LD (2000) Learning from Museums: Visitor Experiences and the Making of Meaning. Plymouth, Minnesota, USA: AltaMira

3. Bell P, Lewenstein B, Shouse AW (2009) Learning Science in Informal Environments: People, Places, and Pursuits. Washington DC, USA: The National Academies Press

4. Rowley J, Williams C (2008) The impact of brand sponsorship of music festivals. Market Intell Plann 26: 781-792

5. Spanier G (2010) Brands want to tune into music festival buzz [online]. London Evening Standard 13 Sep

6. European Commission (2012) Power of Research: a new online game to inspire the scientists of the future. Press Release. http:// ec.europa.eu/research/index.cfm?pg=newsaler $t \& \mid g=e n \& y e a r=2011 \& n a=n a-230211$

7. ScienceDaily (2010) Survey Reveals Ways to Enhance Teens' Interest in Science, Technology, Engineering and Mathematics. http://www. sciencedaily.com/releases/2010/01/ 100128091744.htm

8. Moore A (2008) Transferable Skills for Life Scientists. Heidelberg, Germany: European Molecular Biology Organization. http://www. embo.org/documents/embc_sci_skills.pdf

9. Wellsphere (2012) Senior Life Scientists Believe Science Communication Skills Are
More Important Than Ethical Skills. http:// www.wellsphere.com/general-medicinearticle/senior-life-scientists-believe-sciencecommunication-skills-are-more-importantthan-ethical-skills/920957

10. People Science \& Policy Ltd (2006) Factors Affecting Science Communication: A survey of Scientists and Engineers. London, UK: The Royal Society

11. Meyler SV, Salmona J, Ibouri MT, Besolo A, Rasolondraire E, Radespiel U, Rabarivola C, Chikhi L (2012) Density estimates of two endangered nocturnal lemur species from northern Madagascar: new results and a comparison of commonly used methods. Am J Primatol 74: 412-422

12. Kent $A$ (2002) Patients + research = result! The role of patients and their interest groups in biomedical research. EMBO Rep 3: 707-708

13. Rodrigues S, Mota M, Saúde L, LM, Vidal S, Trindade M (2007) Philanthropy in Portugal. EMBO Rep 8: 613-615
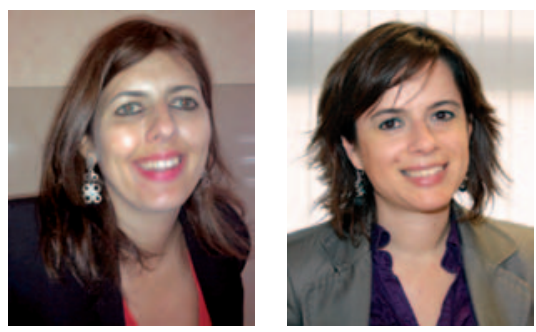

Maria João Leão is Head of Fundraising at the Instituto Gulbenkian de Ciência (IGC), Portugal.

Silvia Castro is Director of Communication at Massachusetts Institute of Technology Portugal Program and was Media Officer at the IGC, Portugal from 2008 to 2011. E-mail:mjleao@igc.gulbenkian.pt

EMBO reports (2012) 13, 954-958; published online 12 October 2012; doi:10.1038/embor.2012.151 